\title{
The Dominant Somatostatin Receptor in Neuroendocrine Tumors of North Indian Population
}

\author{
${ }^{1}$ Narendra Krishnani, ${ }^{2}$ Niraj Kumari, ${ }^{3}$ Rajneesh K Singh, ${ }^{4}$ Pooja Shukla
}

\begin{abstract}
Introduction: Neuroendocrine tumors (NET) express different types of somatostatin receptors (SSTRs) that bind to synthetic analogs with variable affinity. It is important to know the expression profile of SSTRs to predict biological effect of somatostatin analogues. We studied SSTR2 and SSTR5 expression by immunohistochemistry (IHC) to assess the dominant subtype in NETs and correlate the expression with histological prognostic parameters.
\end{abstract}

Materials and methods: Fifty-three consecutive cases of NET from all sites were evaluated for SSTR2 and SSTR5 expression by IHC. The expression was correlated with histological features of NETs.

Results: Forty-four cases were resected specimens and 9 were small biopsies. Nine of 53 cases $(16.9 \%)$ were functional tumors. There were 24 NETs from gastrointestinal tract (GIT), 19 from pancreas and 10 from miscellaneous sites. Overall SSTR expression was seen in 43 NETs $(79.2 \%)$. Somatostatin receptor 2 was expressed in 30 cases (56.6\%) and SSTR5 in 39 cases $(73.6 \%)$. Somatostatin receptor 2 expression showed near significant negative correlation with tumor grade and lymph node metastasis $(p=0.05)$. Somatostatin receptor 5 expression showed significant negative correlation with lymph node metastasis $(p=0.008)$ and tumor size $(p=0.02)$. Anatomic location and tumor necrosis were not significantly different. Somatostatin receptor 5 was dominant subtype expressed in all NETs with intense expression.

Conclusion: Somatostatin receptor 5 expression was the dominant subtype and expressed in small sized tumors. Somatostatin receptor 2 was expressed more in low grade NETs. Somatostatin analogs can be effective both in functional and nonfunctional NETs and can be useful in both resectable and nonresectable or metastatic tumors.

Keywords: Neuroendocrine tumors, Somatostatin analog, SSTR2, SSTR5.

How to cite this article: Krishnani N, Kumari N, Singh RK, Shukla P. The Dominant Somatostatin Receptor in

\footnotetext{
${ }^{1}$ Professor, ${ }^{2,3}$ Additional Professor, ${ }^{4} \mathrm{PhD}$ Student

1,2,4 Department of Pathology, Sanjay Gandhi Post Graduate Institute of Medical Sciences, Lucknow, Uttar Pradesh, India

${ }^{3}$ Department of Surgical Gastroenterology, Sanjay Gandhi Post Graduate Institute of Medical Sciences, Lucknow Uttar Pradesh, India
}

Corresponding Author: Niraj Kumari, Additional Professor Department of Pathology, Sanjay Gandhi Post Graduate Institute of Medical Sciences, Lucknow, Uttar Pradesh, India, Phone: 5222495236, e-mail: niraj@sgpgi.ac.in
Neuroendocrine Tumors of North Indian Population. World $\mathrm{J}$ Endoc Surg 2015;7(3):60-64.

Source of support: Nil

Conflict of interest: None

\section{INTRODUCTION}

Neuroendocrine tumors (NET) are heterogeneous group of neoplasms that arise primarily in gastrointestinal tract (GIT), pancreas and lung. ${ }^{1}$ Ninety percent of these tumors are nonfunctional, that is, they do not produce biologically active peptides but are diagnosed late because of their mass effect. ${ }^{2}$ A common feature of all NETs is expression of different types of somatostatin receptors (SSTRs) which are seen in approximately 80 to $90 \%$ of gastroenteropancreatic neuroendocrine tumors (GEPNET). ${ }^{2,3}$ The expression of different types of SSTRs varies between NETs of different tissues and also in the NET of same tissue. ${ }^{4}$ These SSTRs bind to natural and synthetic somatostatin analogs with variable affinity having the high affinity for SSTR2 and SSTR5 and low for SSTR3. ${ }^{5,6}$ The dominant receptor subtype in majority of NETs is SSTR2 followed by SSTR5, SSTR3 and SSTR1. Somatostatin receptor 4 is the least expressed receptor. ${ }^{1,3,7}$

There are several methods to detect SSTRs including quantification of receptor mRNA, in situ hybridization, immunohistochemistry for receptor proteins and somatostatin receptor scintigraphy. Of these, scintigraphy remains the gold standard however false positive scintigraphy may result from areas of necrosis and inflammation within the tumor. ${ }^{8}$ Immunohistochemistry has certain advantages over other methods as it is a direct visualization of the protein in cell with detection of cell type as well as the receptor type because of variable affinity and expression pattern of these receptors. This is important because SSTRs are not only expressed in NETs but also in other tumors like colorectal cancer, breast cancer, meningioma, neuroblastoma, etc. ${ }^{9}$ It is also expressed in non-neoplastic cells like endothelial cells, lymphocytes, fibroblasts, macrophages, etc. 10,11

Synthetic somatostatin analogs have a longer halflife of 2 hours in contrast to 1 to 3 minutes of the natural somatostatin and therefore, are a choice of treatment in functional NETs. ${ }^{12}$ Because of different expression patterns of SSTRs and a variable affinity of synthetic 
somatostatin analogs, it is important to know the expression profile of SSTRs. The present study was designed with an aim to evaluate the dominant expression patterns of commonly expressed SSTRs having high affinity for synthetic somatostatin analogs in NETs of different anatomic sites.

\section{MATERIALS AND METHODS}

Fifty-three consecutive cases of NET of different sites including gastrointestinal, pancreas, lung, thymus and urinary bladder were reviewed for histological features (differentiation, stage, grade necrosis, mitosis, etc.) within a period of 8 years from 2004 to 2011. Tumors were graded by using mitotic count and proliferative index as estimated by Ki-67 staining (DAKO, dilution 1:100, clone-MIB1), whichever was higher. All the cases were stained with rabbit polyclonal antibodies for SSTR2 and SSTR5 (Thermo-Scientific) at 1:500 and 1:750 dilution respectively. Briefly the antigen retrieval was done in citrate buffer at $\mathrm{pH} 6.0$ for 30 minutes and slides were incubated with primary antibody for 1 hour at room temperature. The secondary antibody (Envision, DAKO, Carpentaria) was incubated for 30 minutes. Tumors with moderate to strong staining in more than $10 \%$ tumor cells were considered positive. Weak cytoplasmic staining was considered negative. Both cytoplasmic and membranous staining pattern was noted. Pancreatic islets were used as positive control for SSTR staining. Resected tumors were graded according to WHO 2010 grading system based on mitotic count and $\mathrm{Ki}-67$ index. ${ }^{13}$

\section{STATISTICS}

Somatostatin receptor 2 and SSTR5 expression were correlated with histological parameters using Chi-square test (SPSS version 15).

\section{RESULTS}

A total of consecutive 53 cases were evaluated. The bulk of cases were from surgical gastroenterology speciality accounting for 31 cases followed by surgical endocrinology speciality with 16 cases whereas five cases of lung NET and one case of urinary bladder NET were from departments of pulmonary medicine and urology respectively. Age ranged from 16 to 81 years with mean of 50.7 years and median of 52 years. Male to female ratio was 1.2:1. Forty-four cases were resected specimens and nine cases were endoscopic or needle biopsies. Nine (16.9\%) cases (7 pancreatic, 1 thymic and 1 duodenal) were functional tumors. All pancreatic tumors were insulinomas whereas one duodenal tumor was a gastrinoma and one thymic tumor had Cushing syndrome. Twenty-four of 53 cases were from GIT, 19 from pancreas and 10 cases of other miscellaneous sites (Table 1). None of the cases had family history of other tumors. Tumor size in the 44 resected cases ranged from 0.5 to $11.5 \mathrm{~cm}$ and in one case multiple tumors of $1 \mathrm{~cm}$ were present. Thirty-one cases were grade I, 16 cases grade II and 6 cases grade III. Somatostatin receptor 2 and SSTR 5 together were expressed in 27 of 53 (50.9\%) cases (Figs 1A to C). Thirty cases (56.6\%) expressed only SSTR2 and 39 cases (73.5\%) expressed only Somatostatin receptor 5 (Table 2). Eleven cases $(20.7 \%)$ were negative for both SSTR subtypes. All the positive cases showed SSTR staining in at least $30 \%$ or more tumor cells. Overall cytoplasmic pattern of expression was more common than cytoplasmic and membranous staining and SSTR5 showed a higher expression compared to SSTR2 in all organ systems

Table 1: Anatomic locations of neuroendocrine tumors with resection and biopsy $(n=53)$

\begin{tabular}{lll}
\hline Site & Resected $(n=44)$ & Biopsy $(n=9)$ \\
\hline Stomach & 6 & 2 \\
Small intestine & 11 & 3 \\
Colon & 1 & - \\
Gallbladder & 1 & - \\
Pancreas & 19 & - \\
Carotid body & 1 & - \\
Thymus & 4 & - \\
Lung & - & 4 \\
Urinary bladder & 1 & - \\
\hline
\end{tabular}

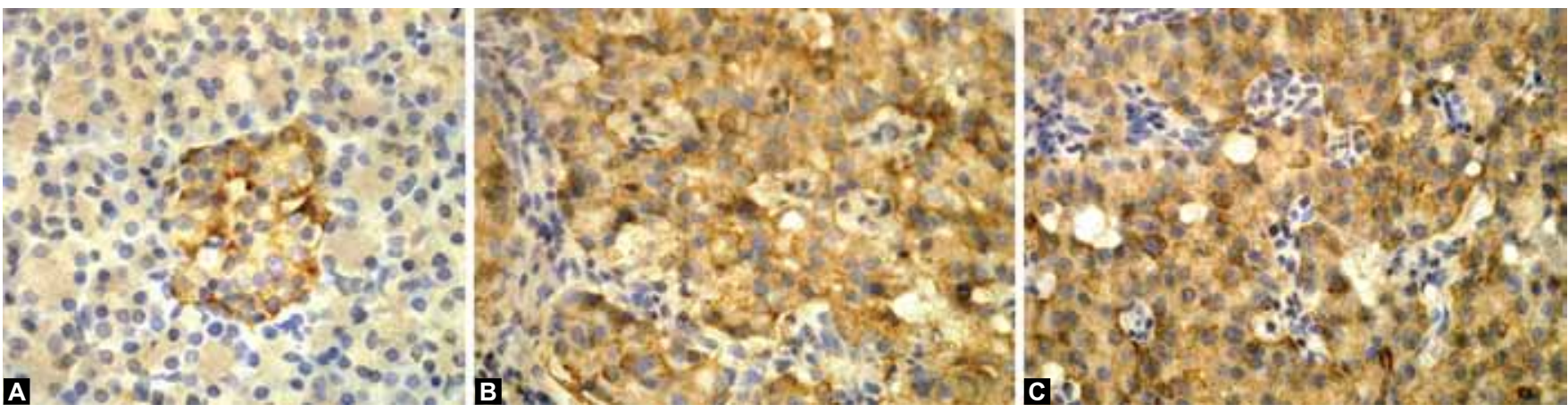

Figs 1A to C: Pancreatic islets as positive control for SSTR expression (Immunohistochemistry, 40x magnification), (B) Cytoplasmic and membranous staining of SSTR2 and (C) SSTR5 (Immunohistochemistry, 40x magnification) 
(Table 3). Somatostatin receptor 2 was expressed more in low grade tumors as classified by mitotic count and Ki-67 labeling index. Both SSTR2 and SSTR5 showed less lymph node metastasis compared to SSTR negative NETs. Somatostatin receptor 5 was expressed more in small size tumors $(<2 \mathrm{~cm}, \mathrm{p}=0.02)$ (Table 4$)$.
Necrosis, anatomic location and tumor stage did not show any correlation with SSTR expression.

\section{DISCUSSION}

Nearly $90 \%$ of GEP-NETs are nonfunctional tumors where surgical excision is the initial and curative approach. ${ }^{2}$

Table 2: Expression profile of somatostatin receptors in different organ systems

\begin{tabular}{lllll}
\hline Receptors & Pancreas $(n=19)$ & Gastrointestinal tract $(n=24)$ & Miscellaneous $(n=10)$ & Total expression $(n=53)$ \\
\hline SSTR2 positive expression & $11(57.9 \%)$ & $13(54.1 \%)$ & $6(60 \%)$ & $30(56.6 \%)$ \\
SSTR5 positive expression & $16(84.2 \%)$ & $16(66.6 \%)$ & $7(70 \%)$ & $39(73.5 \%)$ \\
$\begin{array}{l}\text { Both SSTR2 and SSTR5 } \\
\text { positive expression }\end{array}$ & $11(57.9 \%)$ & $12(50 \%)$ & $4(40 \%)$ & $27(50.9 \%)$ \\
$\begin{array}{l}\text { Both SSTR2 and SSTR5 } \\
\text { negative expression }\end{array}$ & $3(15.7 \%)$ & $7(29.1 \%)$ & $1(10 \%)$ & $11(20.7 \%)$
\end{tabular}

SSTR: Somatostatin receptor

Table 3: Expression of somatostatin receptors and clinicopathological prognostic parameters in resected neuroendocrine tumors at different anatomic sites $(n=44)$

\begin{tabular}{|c|c|c|c|}
\hline Parameters & Pancreas $(n=19)$ & $G I T(n=19)$ & Miscellaneous $(n=6)$ \\
\hline Age range & $16-69$ & $21-81$ & $24-61$ \\
\hline $\mathrm{M}: \mathrm{F}$ & $7: 12$ & $16: 3$ & $1: 1$ \\
\hline Grade & $\mathrm{G} 1=19$ & $\mathrm{G} 1-11, \mathrm{G} 2=8$ & G1-2, G2-4 \\
\hline Size range & $1-11 \mathrm{~cm}$ & $0.5-8 \mathrm{~cm}$ & $4-11.5 \mathrm{~cm}$ \\
\hline Extent of infiltration & $\begin{array}{l}\text { Limited to pancreas }=17 \\
\text { D2 serosa }=1 \\
\text { D2 submucosa }=1\end{array}$ & $\begin{array}{l}\text { Limited to submucosa }=2 \\
\text { Muscle }=8 \\
\text { Serosa }=6 \\
\text { Pancreas }=2 \\
\text { Pancreas }+ \text { CBD }=1\end{array}$ & $\begin{array}{l}\text { Urinary Bladder-perivesical fat } \\
\text { Carotid body } \\
\text { Organ confined } \\
\text { Thymus-capsule infiltration }\end{array}$ \\
\hline Lymph node metastasis & 1 & 8 & 1 \\
\hline Distant metastasis & 1 (liver) & 1 (omentum) & 0 \\
\hline Mitosis (/HPF) & Occasional to $3 / 10 \mathrm{HPF}$ & Occasional to $40 / 10 \mathrm{HPF}$ & Occasional to $10 / 10 \mathrm{HPF}$ \\
\hline Ki-67 labeling index & $0-4.5 \%$ & $0-50 \%$ & $0-10 \%$ \\
\hline Necrosis & 0 & 6 & 0 \\
\hline SSTR2 & 11 & 10 & 4 \\
\hline SSTR5 & 16 & 12 & 4 \\
\hline
\end{tabular}

G1: Grade I; G2: Grade 2; D2: Duodenum; CBD: Common bile duct

Table 4: Correlation of histological prognostic parameters with expression of SSTR2 and SSTR5 in all 53 cases of neuroendocrine tumors

\begin{tabular}{|c|c|c|c|c|c|c|}
\hline Tumor characteristics & $\begin{array}{l}\text { SSTR2 positive } \\
\text { NETS }(n=30)\end{array}$ & $\begin{array}{l}\text { SSTR2 negative } \\
\text { NETS }(n=23)\end{array}$ & $p$-value & $\begin{array}{l}\text { SSTR5 expression } \\
(n=39)\end{array}$ & $\begin{array}{l}\text { SSTR5 negative NETS } \\
(n=14)\end{array}$ & $p$-value \\
\hline Location & - & - & 0.2 & - & - & 0.3 \\
\hline Pancreas & 11 & 8 & - & 16 & 3 & - \\
\hline Stomach & 6 & 1 & - & 6 & 1 & - \\
\hline Intestine & 7 & 10 & - & 10 & 7 & - \\
\hline Miscellaneous & 6 & 4 & - & 7 & 3 & - \\
\hline Size & - & - & 0.2 & - & - & 0.02 \\
\hline $0-2 \mathrm{~cm}$ & 13 & 8 & - & 19 & 2 & - \\
\hline $2.1-5 \mathrm{~cm}$ & 14 & 10 & - & 14 & 10 & - \\
\hline $5.1-10 \mathrm{~cm}$ & 2 & 3 & - & 3 & 2 & - \\
\hline$>10 \mathrm{~cm}$ & 1 & 2 & - & 3 & 0 & - \\
\hline Grade & - & - & 0.05 & - & - & 0.1 \\
\hline Grade I & 21 & 10 & - & 26 & 5 & - \\
\hline Grade II & 5 & 11 & - & 9 & 7 & - \\
\hline Grade III & 4 & 2 & - & 4 & 2 & - \\
\hline Necrosis & 6 & 4 & 0.7 & 7 & 3 & 0.4 \\
\hline Lymph node metastasis & 3 & 7 & 0.05 & 4 & 6 & 0.007 \\
\hline
\end{tabular}


However about $10 \%$ of tumors are functional and produce systemic symptoms affecting the quality of life. In these functioning tumors and metastatic or unresectable tumors, the approach is to improve the quality of life by giving synthetic somatostatin analogs. The synthetic somatostatin analogs which have a longer half-life than naturally occurring somatostatins act through different SSTRs present on the cell surface of neuroendocrine and other non-neuroendocrine tumors and act by inhibiting the release of different endocrine hormones as well as by anti-proliferative affect which is helpful even in nonfunctioning tumors. The anti-proliferative effect mediates directly by cell cycle arrest and inducing apoptosis and indirectly by decreasing growth factors, inhibiting angiogenesis and immunomodulation. ${ }^{1,14}$ The natural somatostatin binds with all SSTR subtypes but the synthetic analogs have variable affinity with different receptor types. Most of the synthetic analogs act through SSTR2 and SSTR5 whereas the newer panreceptor agonist, pasireotide, binds SSTR5, SSTR3 and SSTR1 with much higher affinity than SSTR2. ${ }^{14-16}$

In the present study overall SSTR expression was seen in $79.2 \%$ of NETs from different anatomic sites with SSTR5 expression in $73.6 \%$ and SSTR2 expression in $56.6 \%$ tumors. We found combined cytoplasmic and membranous pattern of positivity in both the receptor subtypes. There are few reports on immunohistochemical expression of SSTRs in NETs. Most of the studies have shown a high SSTR2 expression of more than $80 \%{ }^{17,18}$ Papotti et al studied three receptors-SSTR 2, 3 and 5 and found an overall SSTR expression of $75 \%$ in 81 cases. They found nearly equal expression of SSTR2 (68.2\%) and SSTR5 (63.6\%) and lower expression for SSTR3 $(36.4 \%){ }^{3}$ Takei et al studied both SSTR2 and SSTR5 and found $100 \%$ positivity for SSTR2 and $94.5 \%$ for SSTR $5 .{ }^{19}$ Pisarek et al studied all six somatostatin receptors (SSTR1, 2A, 2B, 3,4 and 5) and found SSTR2 (47.1\%) expression less than SSTR5 (58.8\%). ${ }^{20}$ Similarly Nasir et al also found SSTR5 (91\%) to show higher expression than SSTR2 (81\%) which they explained was because of patients receiving synthetic somatostatin analog therapy at the time of surgery and SSTRs are internalized into the cytoplasm with synthetic analog therapy. ${ }^{21}$ In the present study also SSTR5 (73.5\%) had higher expression than SSTR2 (56.6\%) and none of the patients were on synthetic analog therapy during surgery.

Reubi et al studied SSTRs by receptor autoradiography technique and showed higher level of expression in well differentiated tumors than poorly differentiated tumors. $^{22}$ Volante et al showed 79\% expression of STTRs in well differentiated tumors and $44 \%$ in poorly differentiated NETs. ${ }^{11}$ Similarly in the present study either one or both SSTRs were seen in $78.2 \%$ of well differentiated
NETs and $75 \%$ of poorly differentiated NETs. Both receptor subtypes was negative in $21.8 \%$ of well differentiated and $25 \%$ of poorly differentiated tumors.

Because of different mechanism of effect, variable affinity to the synthetic analogs and also variable expression on different tumor subtypes of the different SSTRs, it is beneficial to have knowledge of the receptor subtype expression on particular tumor before starting patient on synthetic analogs. Although somatostatin scintigraphy is the gold standard, immunohistochemistry has the advantage of in situ localization with cell type and receptor type identification and also avoids false positivity.

\section{CONCLUSION}

The present study showed SSTR5 to be the dominant subtype expressed in NETs of different anatomic sites. The expression of SSTR2 was more in low grade tumors and SSTR5 was commonly expressed in small sized NETs $(<2 \mathrm{~cm})$. Somatostatin receptors apart from being useful in functioning tumors may be useful in nonfunctioning and non-resectable tumors because of their antimitotic activity.

\section{ACKNOWLEDGMENT}

The work was funded by Institute's Intramural Research Funding Committee (PGI/DIR/RC/268/2010).

\section{REFERENCES}

1. Toumpanakis C, Caplin ME. Update on the role of somatostatin analogs for the treatment of patients with gastroenteropancreatic neuroendocrine tumors. Semin Oncol 2013;40(1):56-68.

2. Ramage JK, Davies AH, Ardill J, Bax N, Caplin M, Grossman A, Hawkins R, McNicol AM, Reed N, Sutton R, et al. UKNET work for neuroendocrine tumours: guidelines for the management of gastroenteropancreatic neuroendocrine (including carcinoid) tumours. Gut 2005 June;54(Suppl 4):1-16.

3. Papotti M, Bongiovanni M, Volante $M$, Allìa E, Landolfi S, Helboe L, Schindler M, Cole SL, Bussolati G. Expression of somatostatin receptor types 1-5 in 81 cases of gastrointestinal and pancreatic endocrine tumors. A correlative immunohistochemical and reverse-transcriptase polymerase chain reaction analysis. Virchows Arch 2002;440(5):461-475.

4. Kulaksiz H, Eissele R, Rössler D, Schulz S, Höllt V, Cetin Y, Arnold R. Identification of somatostatin receptor subtypes 1 , $2 \mathrm{~A}, 3$ and 5 in neuroendocrine tumours with subtype specific antibodies. Gut 2002;50(10):52-60.

5. Weckbecker G, Lewis I, Albert R, Schmid HA, Hoyer D, Bruns C. Opportunities in somatostatin research: biological, chemical and therapeutic aspects. Nat Rev Drug Discov 2003; 2(12):999-1017.

6. Patel YC. Somatostatin and its receptor family. Frontiers Neuroendocrinol 1999;20(3):157-198.

7. Oberg KE, Reubi JC, Kwekkeboom DJ, Krenning EP. Role of somatostatins in gastroenteropancreatic neuroendocrine tumor development and therapy. Gastroenterol 2010;139(3): 742-753. 
8. Papotti M, Croce S, Bello M, et al. Expression of somatostatin receptor types 2, 3 and 5 in biopsies and surgical specimens of human lung tumours. Correlation with preoperative octreotidescintigraphy. Virchows Arch 2001;439(6):787-797.

9. Reubi JC. Peptide receptors as molecular targets for cancer diagnosis and therapy. Endocr Rev 2003;24(4):389-427.

10. Taniyama Y, Suzuki T, Ikami Y, Moriya T, Satomi S, Sasano H. Systemic distribution of somatostatin receptor subtypes in human: an immunohistochemical study. Endocr J 2005;52(5): 605-611.

11. Volante M, Brizzi MP, Faggiano A, Rosa SL, Rapa I, Ferrero A, Mansueto G, Righi1 L, Garancini S, Capella C, et al. Somatostatin receptor type $2 \mathrm{~A}$ immunohistochemistry in neuroendocrine tumors: a proposal of scoring system correlated with somatostatin receptor scintigraphy. Mod Pathol 2007;20(11):1172-1182.

12. Oberg K. Future aspects of somatostatin-receptor-mediated therapy. Neuroendocrinol 2004;80(Suppl 1):57-61.

13. Klimstra DS, Modlin IR, Coppola D, Lloyd RV, Suster S. The pathologic classification of neuroendocrine tumors: a review of nomenclature, grading and staging systems. Pancreas 2010;39(6):707-712.

14. Appetecchia M, Baldelli R. Somatostatin analogues in the treatment of gastroenteropancreatic neuroendocrine tumours, current aspects and new perspectives. J Experiment Clin Cancer Res 2010 Mar 2;29:19. Available at: http://www.jeccr. com/content/29/1/19.

15. Bergsland EK. The evolving landscape of neuroendocrine tumors. Semin Oncol 2013;40(1):4-22.

16. Bruns C, Lewis I, Briner U, Meno-Tetang G, Weckbecker G. SOM230: a novel somatostatin peptidomimetic with broad somatotropin release inhibiting factor (SRIF) receptor binding and a unique antisecretory profile. Eur J Endocrinol 2002;146(5):707-716.

17. Oberg K, Kvols L, Caplin M, et al. Consensus report of the use of somatostatin analogs for the management of neuroendocrine tumors of the gastroenteropancreatic system. Ann Oncol 2004;15(6):966-973.

18. Reubi JC, Waser B, Schaer JC, Laissue JA. Somatostatin receptor SSTR1-SSTR5 expression in normal and neoplastic human tissues using receptor autoradiography with subtype-selective ligands. Eur J Nucl Med 2001;28(7): 836-846.

19. Takei M, Suzuki M, Kajiya H, Ishii Y, Tahara S, Miyakoshi T, Egashira N, Takekoshi S, Sanno N, Teramoto A, et al. Immunohistochemical detection of somatostatin receptor (SSTR) subtypes $2 \mathrm{~A}$ and 5 in pituitary adenoma from acromegalic patients: good correlation with preoperative response to octreotide. Endocr Pathol 2007;18(4):208-216.

20. Pisarek H, Pawlikowski M, Kunert-Radek J, Kubiak R, Winczyk K. SSTR1 and SSTR5 subtypes are the dominant forms of somatostatin receptor in neuroendocrine tumors. Folia Histochem Cytobiol 2010 Jan 1;48(1):142-147.

21. Nasir A, Stridsberg M, Strosberg J, et al. Somatostatin receptor profiling in hepatic metastases from small intestinal and pancreatic neuroendocrine neoplasms: immunohistochemical approach with potential clinical utility. Cancer Control 2006;13(1):52-60.

22. Reubi JC, Kvols LK, Waser B, et al. Detection of somatostatin receptors in surgical and cell carcinomas percutaneous needle biopsy samples of carcinoids and islet detection. Cancer Res 1990;50(18):5969-5977. 